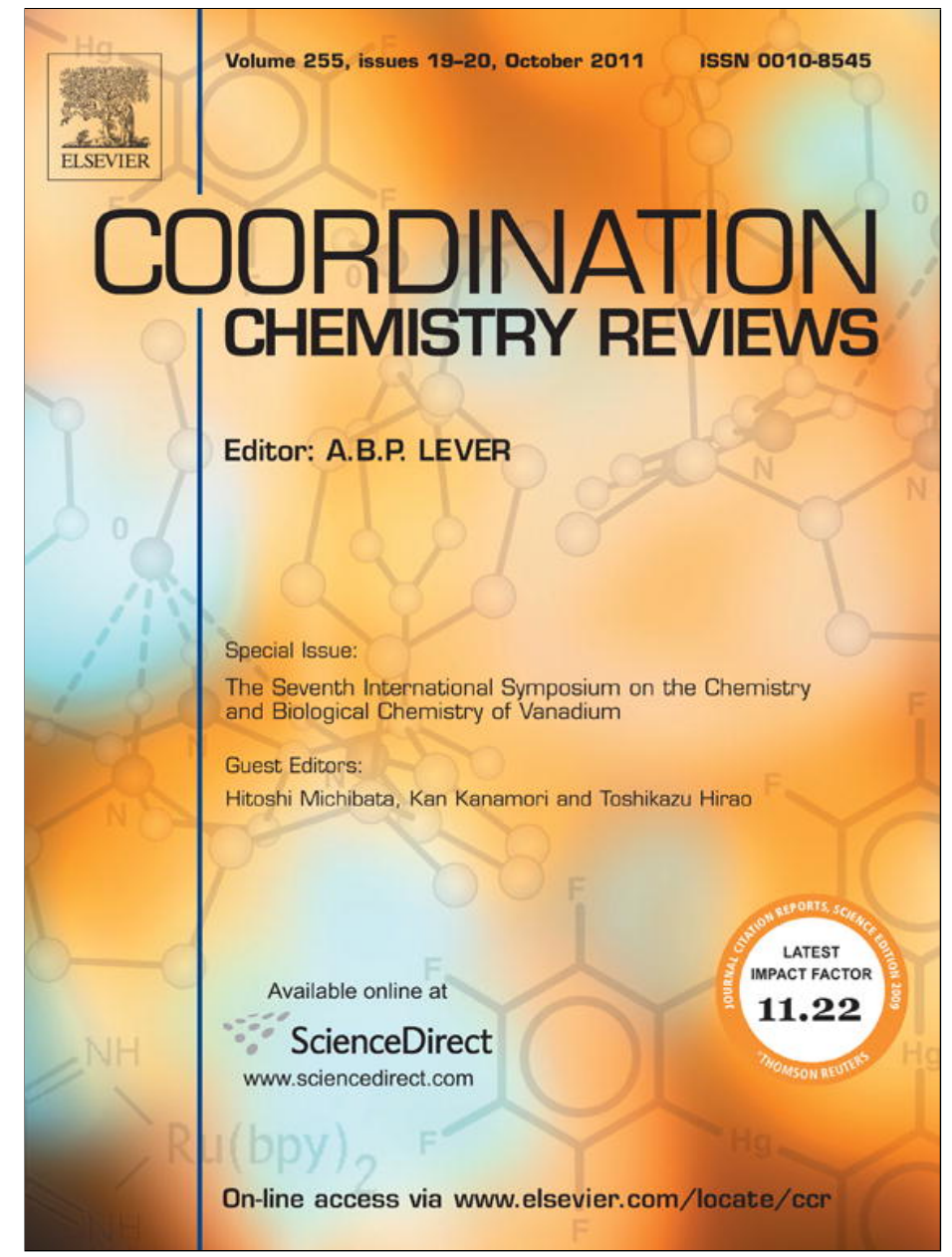

This article appeared in a journal published by Elsevier. The attached copy is furnished to the author for internal non-commercial research and education use, including for instruction at the authors institution and sharing with colleagues.

Other uses, including reproduction and distribution, or selling or licensing copies, or posting to personal, institutional or third party websites are prohibited.

In most cases authors are permitted to post their version of the article (e.g. in Word or Tex form) to their personal website or institutional repository. Authors requiring further information regarding Elsevier's archiving and manuscript policies are encouraged to visit:

http://www.elsevier.com/copyright 
Review

\title{
Recent advances in vanadium catalyzed oxygen transfer reactions
}

\author{
Giulia Licini ${ }^{\mathrm{a}, *}$ Valeria Conte $^{\mathrm{b}}$, Alessia Coletti $^{\mathrm{b}}$, Miriam Mba $^{\mathrm{a}}$, Cristiano Zonta $^{\mathrm{a}}$ \\ a Dipartimento di Scienze Chimiche, Università di Padova, Via Marzolo 1, 35131 Padova, Italy \\ b Dipartimento di Scienze e Tecnologie Chimiche, Università di Roma “Tor Vergata”, Via della Ricerca Scientifica snc, 00133 Roma, Italy
}

\section{Contents}

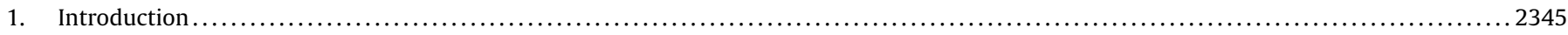

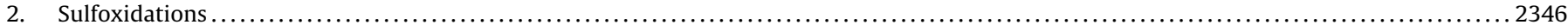

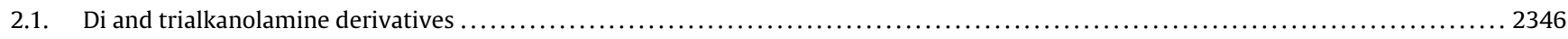

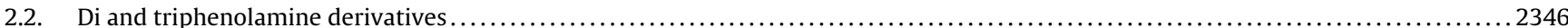

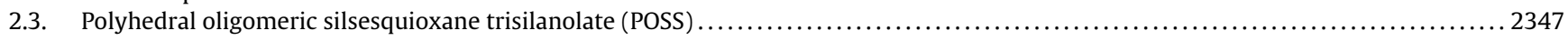

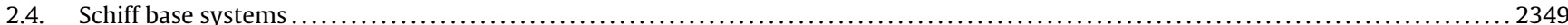

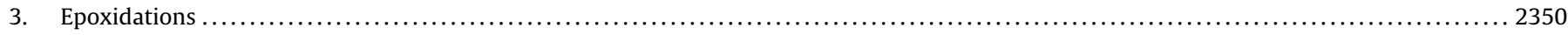

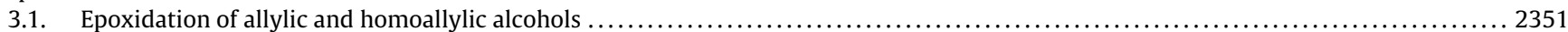

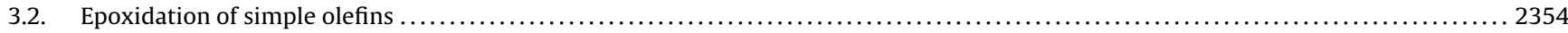

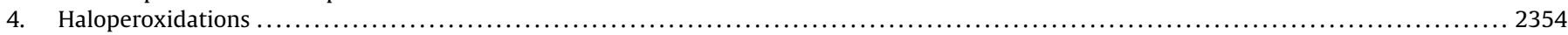

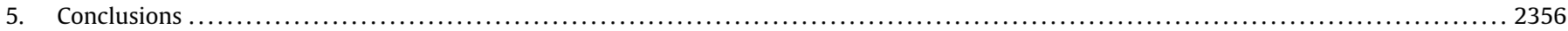

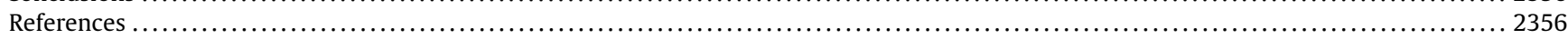

\section{A R T I C L E I N F O}

\section{Article history:}

Received 20 February 2011

Accepted 1 May 2011

Available online 7 May 2011

\section{Keywords:}

Vanadium

Oxidations

Epoxidation

Sulfoxidation

Haloperoxidation

Alkyl hydroperoxides

Hydrogen peroxide

\begin{abstract}
A B S T R A C T
Vanadium complexes have proven to be effective catalysts for the activation of peroxides and the selective oxidation of substrates like bromides, sulfides and alkenes. Besides their capability to form metalloperoxo species, which effectively transfer oxygen atoms to the substrate, these systems are synthetically useful for obtaining valuable oxidized molecules on a preparative scale, with a high degree of selectivity and TONs. Furthermore, the use of environmentally friendly oxidants like hydrogen and alkyl hydroperoxides increases significantly their potential application at an industrial level.

Here we report a critical survey on the most effective homogeneous vanadium catalysts reported in the last decade concerning their synthetic application in oxygen transfer reactions (sulfoxidation, epoxidation, haloperoxidation) using hydrogen peroxide or alkyl hydroperoxides, demonstrating the different classes of ligands and complexes, their catalytic performances, their reactivity, chemo, stereo and substrate selectivity. Some examples of the use of non conventional reaction media or techniques and catalyst recycling studies will be also discussed.
\end{abstract}

(c) 2011 Elsevier B.V. All rights reserved.

\section{Introduction}

The capability of $d^{0}$ metal complexes to catalyze oxygen transfer reactions has received much attention during the past thirty years [1]. These metals are able to activate peroxides such as hydrogen peroxide, cumyl or $t$-butyl hydroperoxide for the oxidation to a large variety of substrates, and, with the addition of proper chiral ligands, high degrees of stereoselectivity have been achieved. In our groups we have been largely interested in oxygen transfer reactions involving zirconium [2], titanium [3], molybdenum [4]

\footnotetext{
* Corresponding author.

E-mail address: giulia.licini@unipd.it (G. Licini).
}

and vanadium [5] based catalysts. In particular vanadium catalyzed oxidations have attracted our attention by virtue of the interesting properties of this metal in terms of selectivity, reactivity and stereoselectivity. Indeed, vanadium mediated oxygen transfer reactions are frequently applied in chemical research, and in recent years, important advances have been achieved. In this context, vanadium catalyzed oxygen transfer reactions have gained renewed interest due to the discovery of vanadium-dependent haloperoxidase (VHPO) enzymes able to activate hydrogen peroxide for the oxidation of halides with the consequent production of halogenated compounds and the stereoselective sulfoxidations [6].

Peroxovanadium complexes, depending on the nature of the ligands coordinated to the metal and on the experimental conditions, can act either as electrophilic oxygen transfer reagents 
<smiles>[R20]OCCN(CC(O)c1ccccc1)C([R])C([R])O</smiles>

1a $\mathrm{R}=\mathrm{H}, \mathrm{R}^{\prime}=\mathrm{Ph}, \mathrm{R}^{\prime \prime}=t \mathrm{Bu}$ 1b $\mathrm{R}=\mathrm{H}, \mathrm{R}^{\prime}=\mathrm{Ph}, \mathrm{R}^{\prime \prime}=\mathrm{Me}$ 1c $\mathrm{R}=\mathrm{Ph}, \mathrm{R}^{\prime}=\mathrm{H}, \mathrm{R}^{\prime \prime}=t \mathrm{Bu}$ 1d $\mathrm{R}=\mathrm{Ph}, \mathrm{R}^{\prime}=\mathrm{H}, \mathrm{R}^{\prime \prime}=\mathrm{Me}$<smiles>[R]C([R])N(C[C@@H](C)O)C[C@@H](C)O</smiles>

2a $R=M e, R^{\prime}=P h$

2b R=H, R'=Ph

2c $\mathrm{R}=\mathrm{R}^{\prime}=\mathrm{Me}$<smiles>OCCN(C[C@H](O)P)C[Pb](O)C(P)(CO)CO</smiles>

3

Fig. 1. Synthesis of enantiopure bis-alkanolamines 1-3 derived from $(R)$-styrene oxide or (S)-propene oxide [8].

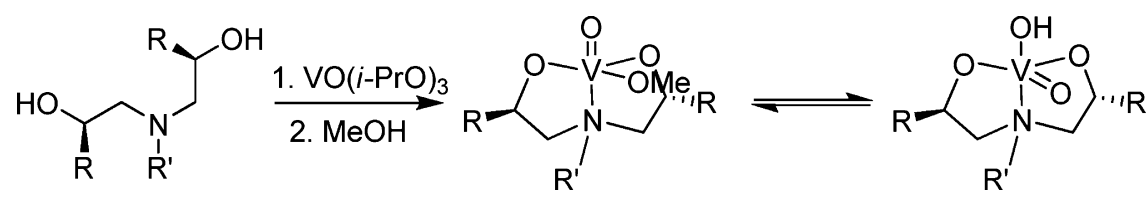

Scheme 1. Interconversion of $\mathrm{V}(\mathrm{V})$ diastereomeric complexes obtained from ligands 1-3, presenting an equatorial or an axial vanadium oxo function [8].

or as radical oxidants. Typical electrophilic processes are the oxidation of sulfides and tertiary amines and the epoxidation of allylic alcohol or simple alkenes. The oxidation of alcohols and the hydroxylation of aliphatic and aromatic hydrocarbons are examples of homolytic reactivity. This contribution reviews the vanadium-catalyzed oxidations in which electrophilic oxygen transfer reactions are taking place. This translates to the oxidation of sulfides, alkenes, halides which have been studied in the presence of terminal oxidants such as molecular oxygen, hydrogen peroxide, and alkyl hydroperoxides. Thus, Section 2 is devoted to sulfoxidations, while Section 3 presents epoxidations. In both these sections great emphasis is given to the stereoselective processes. The oxidation of halides, haloperoxidation, is discussed in Section 4. All the processes in which vanadium catalysts react in a heterolytic fashion have been considered. Several review articles have appeared on vanadium-catalyzed oxidation [6,7], consequently, the present review emphasizes the work published during the past 7-10 years covering studies up to 2010 .

\section{Sulfoxidations}

Vanadium catalyzed sulfoxidation is an important transformation both for the relevance of the products obtained (sulfoxides and sulfones) and for the information that this reaction can give on the nature of the active peroxo species involved into the process and the mechanism of the oxygen transfer. Furthermore the process can be chemo and stereoselective, yielding mainly sulfoxides with high enantiomeric excesses [7].

\subsection{Di and trialkanolamine derivatives}

In 2003 a series of enantiopure bis-alkanolamines were synthesized by Rehder and coworkers as models of vanadate-dependent peroxidases [8]. The ligands were prepared by the aminolysis of enantiopure $(R)$-styrene oxide or $(S)$-propylene oxide with different primary amines (Fig. 1).
The coordination chemistry of the new class of ligands 1-3 has been investigated by reaction with $\mathrm{VO}(\mathrm{O}-i-\mathrm{Pr})_{3}$. Usually a mixture of mononuclear complexes with a distorted trigonal bipyramidal geometry was obtained, equilibrating among the possible diastereomeric forms having an equatorial or an axial vanadium oxo function (Scheme 1).

These complexes have been characterized both via X-ray diffraction and, in solution, ${ }^{1} \mathrm{H}$ and ${ }^{51} \mathrm{~V}$ NMR, also at variable temperature. The catalytic performances of the new complexes in sulfoxidation have been tested using alkyl hydroperoxides as oxygen source [tertbutyl peroxide (TBHP) or cumyl peroxide (CHP)] in chloroform on methyl $p$-tolyl sulfide $\mathbf{4}$ or benzyl phenyl sulfide $\mathbf{5}$. The best results obtained in these studies, with respect mainly to the reactivity and stereoselectivity of the process, are reported in Table 1.

Stereoselectivities up to $38 \%$ were obtained in satisfactory chemical yields and selectivity towards sulfoxide formation. The absolute stereochemistry of the dialkanolamine controls the stereoselection of the oxygen transfer process $[(S, S)$ ligands afford $(S)$-sulfoxides, $(R, R)$ ligands give the $(R)$-ones].

More recently Martinez and Dutasta reported on the synthesis and catalytic performance in the sulfoxidation of methyl p-tolyl sulfide $\mathbf{4}$ and benzyl phenyl sulfide $\mathbf{5}$ of enantiopure hemicryptophane-vanadium oxo complexes 6 and 7 (Fig. 2) [9].

The supramolecular catalysts $\mathbf{6}$ and $\mathbf{7}$ catalyze the sulfoxidation of both substrates in the presence of CHP with catalyst loading down to $0.5 \%$, chemical yields up to $95 \%$, high sulfoxide/sulfone selectivity (98-100\%) and TON up to 180 . Interestingly, reactions carried out with the model catalyst $\mathbf{8}$ give much lower yields (25-46\%). As far as the stereoselectivity of the systems is concerned, the authors report enantiomeric excesses around 10\% independently from the enantiopure vanadium complex employed and from the ratio of the two possible $\Lambda / \Delta$ diastereomers.

\subsection{Di and triphenolamine derivatives}

$C_{3} \mathrm{~V}(\mathrm{~V})$ amino triphenolates have been prepared and tested as haloperoxidase structural and functional models by Licini and

\section{Table 1}

Oxidation of methyl $p$-tolyl sulfide $\mathbf{4}$ or benzyl phenyl sulfide $\mathbf{5}$ by TBHP or CHP in the presence of $\mathrm{V}(\mathrm{V}) / \mathbf{1}-\mathbf{3}$ catalysts at $0-20{ }^{\circ} \mathrm{C}$. Substrate:oxidant: $\mathrm{V}(\mathrm{V})=10: 10: 1$ ([sulfide $\left.]_{0}=0.1 \mathrm{M}\right)[8]$.

\begin{tabular}{|c|c|c|c|c|c|c|c|}
\hline Entry & Substrate & Ligand & Time $(\mathrm{h})$ & Conv (\%) & $\mathrm{SO} / \mathrm{SO}_{2}$ & Ees (conf) & Ref. \\
\hline 1 & 4 & $2 a$ & $2.5\left(0^{\circ} \mathrm{C}\right)$ & 100 & $85: 15$ & $31(S)$ & [8a] \\
\hline 2 & 5 & $\mathbf{2 a}$ & $4.5\left(0^{\circ} \mathrm{C}\right)$ & 100 & $79: 21$ & $23(S)$ & [8a] \\
\hline 3 & 4 & $1 a$ & $2.0\left(-20^{\circ} \mathrm{C}\right)$ & 70 & $93: 7$ & $38(R)$ & [8b] \\
\hline 4 & 5 & $1 a$ & $0.33\left(-20^{\circ} \mathrm{C}\right)$ & 70 & $96: 4$ & $37(R)$ & [8b] \\
\hline 5 & 4 & 3 & $3.0\left(0^{\circ} \mathrm{C}\right)$ & 60 & $95: 5$ & $37(R)$ & {$[8 c]$} \\
\hline
\end{tabular}




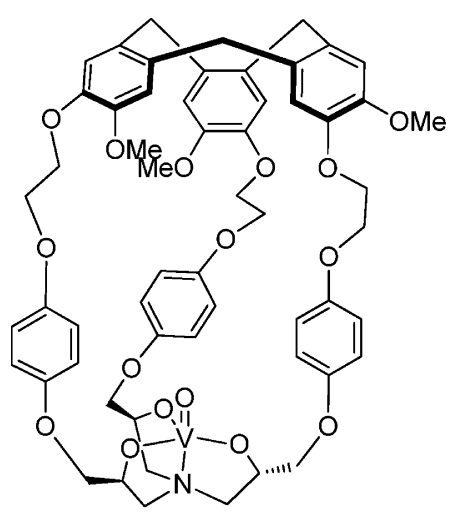

6

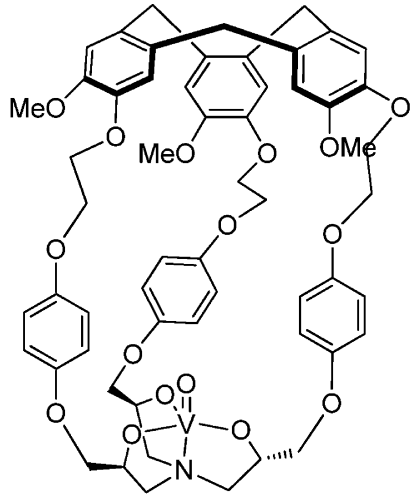

7

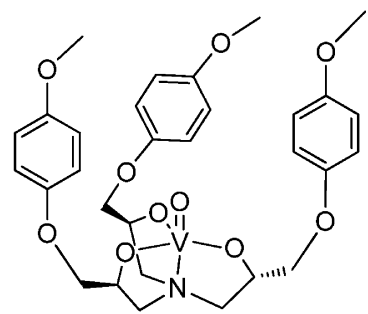

8

Fig. 2. Dutasta enantiopure hemicryptophane-vanadium oxo complexes 6, 7 and the model system 8 [9].<smiles>[R]c1cccc(CN(Cc2cccc([R])c2O)Cc2cccc([R])c2O)c1O</smiles><smiles>CC(C)CC(C)C(=O)O</smiles>

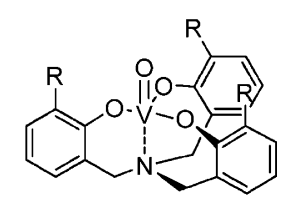

10a $\mathrm{R}=\mathrm{H}$, 10b $\mathrm{R}=\mathrm{Me}$ 10c $R=t-B u$

Scheme 2. Amino triphenolate vanadium complexes 10a-c [10].

coworkers [10]. Triphenolamine $\mathbf{9}$ can be easily prepared via threefold reductive amination of salicylic aldehyde derivatives [11]. Reaction of 9 with $\mathrm{VO}(\mathrm{O}-i-\mathrm{Pr})_{3}$ affords in high yields of the mononuclear $C_{3}$ complexes $10 \mathbf{b}(\mathrm{R}=\mathrm{Me})$ and 10c $(\mathrm{R}=t$-Bu) as deep red crystalline solids, which were characterized by ${ }^{1} \mathrm{H}$ and ${ }^{51} \mathrm{~V} \mathrm{NMR}$ and $\mathrm{X}$-ray diffractometric analysis (Scheme 2). Complex 10a derived from the less hindered ligand 10a shows more complex NMR spectra consistent with the formation of aggregates/mixture of species.

The catalytic performances of complexes 10a-c (10\%) were tested in the sulfoxidation of thioanisole $\mathbf{1 1}$ with hydrogen peroxide as primary oxidant under homogeneous conditions (methanol). All three mononuclear catalysts gave fast and totally selective conversion into the sulfoxide and in the case of 10c $(R=t-B u)$ with quantitative yields. This system was further optimized decreasing the catalyst loading down to $0.01 \%$. Methyl phenyl sulfoxide $\mathbf{1 2}$ was obtained in quantitative yields and very high selectivity with respect to methyl phenyl sulfone 13, reaching TONs up to 9900 and TOF up to $8000 \mathrm{~h}^{-1}$ working with [sulfide $]_{0}=1.0 \mathrm{M}$ and more concentrated $\mathrm{H}_{2} \mathrm{O}_{2}$ (70\%) (Table 2, entries 3 and 5).

The optimized procedure was used for determining the scope of the reaction with a series of sulfides (Fig. 3). In all case chemical yields over $94 \%$ were obtained with very high $\mathrm{SO} / \mathrm{SO}_{2}$ selectivities, results that are in line with an electrophilic oxygen transfer process and prove the synthetic applicability of the method on a preparative scale.

Other V(V) catalysts containing amino phenolate-based ligands were reported by Martins and coworkers [12]. Ligands 14a,b were prepared via Mannich condensation from the corresponding o, $p$ di(tert-butyl)phenols and different bis-amines (Fig. 4) [13]. The authors prepared the vanadium(III) complexes $\mathbf{1 5 a}, \mathbf{b}$ by reaction with $\mathrm{VCl}_{3}(\mathrm{THF})_{3}$. Oxidation by air gave the corresponding vana$\operatorname{dium}(\mathrm{V})$ complexes 16a,b, whose ${ }^{1} \mathrm{H}$ and ${ }^{13} \mathrm{C}$ NMR are compatible with an average $C_{\mathrm{s}}$ octahedral geometry with trans phenolate coordination and an axial oxo group. Addition of $i$-PrOLi gave 17a as a

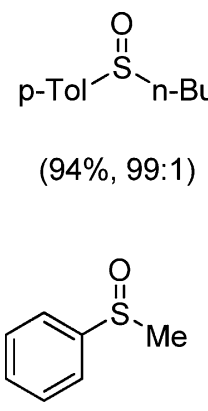

$98 \%>99: 1$<smiles>CCCC[Pb]S(=O)CCCC</smiles><smiles>O=S(Br)c1ccccc1</smiles>

$(91 \%,>99: 1)$

$(99 \%,>99: 1)$<smiles>COc1ccc(S(C)=O)cc1</smiles>

$70 \% 97: 3$
$94 \%>99: 1$
Fig. 3. Sulfoxides obtained by sulfoxidation by $30 \%$ aqueous $\mathrm{H}_{2} \mathrm{O}_{2}$ catalyzed by 9 c (0.1\%) (Chemical yields, sulfoxide, sulfone selectivity.) [10].

diastereomeric mixture having the vanadium oxo function equatorial or axial. On the contrary, the chiral complex $(R)-\mathbf{1 7 b}$ shows ${ }^{1} \mathrm{H}$ and ${ }^{13} \mathrm{C}$ NMR spectra consistent with a $C_{1}$ octahedral complex, with an axial oxo group. Most of these complexes have been characterized via X-ray analysis (Fig. 4).

The catalytic activity of these complexes has been investigated using $\mathrm{H}_{2} \mathrm{O}_{2}$ (20\%) in slight excess in the presence of $1 \%$ catalyst using different solvents and reaction temperatures. The best results are reported in Table 3.

The most reactive and selective catalyst is $(R)-\mathbf{1 6 b}$ in homogeneous phase (acetone) at $0^{\circ} \mathrm{C}$ (Table 3 , entry 4). Complete conversion with high $\mathrm{SO} / \mathrm{SO}_{2}$ selectivity was obtained already after $4 \mathrm{~h}$. The same system provided much lower conversions under biphasic systems (DCE/ $\mathrm{H}_{2} \mathrm{O}$, Tables 3 and 4, entries 2-3). The biphasic system provides better results when the catalysts are prepared in situ from $\mathrm{VO}(\mathrm{acac})_{2}$ reaching $91 \%$ conversions after $24 \mathrm{~h}$ (Table 3 , entries 6 and 7). In all the cases no enantiomeric excesses were obtained using the chiral catalysts.

\subsection{Polyhedral oligomeric silsesquioxane trisilanolate (POSS)}

Polyhedral oligomeric silsesquioxane trisilanolate $V(V)$ complex 18 catalyzes the sulfoxidation, as well as amine oxidation to nitrones or $N$-oxides (Scheme 3) [14].

Quantitative yields were obtained in the oxidation of methyl $p$ tolyl sulfide $\mathbf{4}$ with CHP working at room temperature with high sulfoxide/sulfone selectivity (Table 4, entry 1 ). Furthermore in the presence of Lewis base coligands a significant increase of the reactivity (up to 24 fold) could be obtained associated with decreased sulfoxide/sulfone selectivity (Table 4 ). 
Table 2

Oxidation of thioanisole $\mathbf{1 1}$ by aqueous hydrogen peroxide catalyzed by $\mathbf{1 0 c} .^{\mathrm{a}}$ Effect of concentration and catalyst loading [10].

\begin{tabular}{|c|c|c|c|c|c|c|c|}
\hline Entry & {$[\mathbf{1 1}]_{0}(\mathrm{M})$} & $\mathbf{9 c}(\%)$ & Yields (\%) & $12: 13$ & Time (min) & TON & $\operatorname{TOF}\left(\mathrm{h}^{-1}\right)$ \\
\hline 1 & 0.1 & 1 & 97 & $96: 4$ & 25 & 97 & 240 \\
\hline 2 & 1.0 & 0.1 & 98 & $98: 2$ & 80 & 980 & 1330 \\
\hline 3 & $1.0^{\mathrm{b}}$ & 0.1 & 98 & $97: 3$ & 20 & 980 & 8000 \\
\hline 4 & 1.0 & 0.01 & 97 & $97: 3$ & 850 & 9700 & 1790 \\
\hline 5 & $1.0^{\mathrm{b}}$ & 0.01 & 99 & $98: 2$ & 255 & 9900 & 2667 \\
\hline
\end{tabular}

a Reactions were carried out at $28^{\circ} \mathrm{C}$ in $\mathrm{CD}_{3} \mathrm{OD}$ using a $1: 1$ molar ratio of substrate $/ \mathrm{H}_{2} \mathrm{O}_{2}$ (35\% in water).

b Reactions performed with $\mathrm{H}_{2} \mathrm{O}_{2}, 70 \%$ in water.<smiles>[R]C(CN(C)C)N(Cc1cc(C(C)(C)C)cc(C(C)(C)C)c1O)Cc1cc(C(C)(C)C)cc(C(C)(C)C)c1O</smiles>

14a $\mathrm{R}=\mathrm{H}$,

14b $\mathrm{R}=\mathrm{Me}$

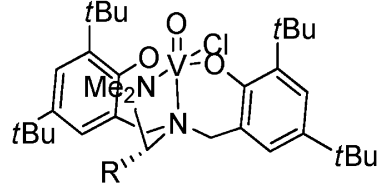

15a $\mathrm{R}=\mathrm{H}$

15b $\mathrm{R}=\mathrm{Me}$

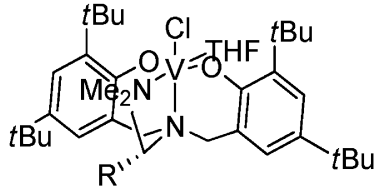

$16 \mathrm{a} \mathrm{R}=\mathrm{H}$

$16 \mathrm{~b}$ R=Me

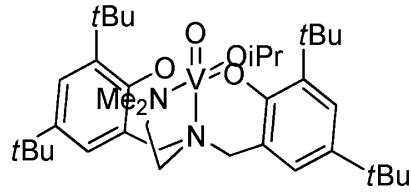

$17 a$, mixture os diastereomers<smiles>CC(C)(C)O[PH]12(=O)Oc3c4cc(C(C)(C)C)cc3CN1N(C4)Cc1cc(C(C)(C)C)cc(C(C)(C)C)c1O2</smiles>

Bu

Fig. 4. Amino bis-phenols 14 and the corresponding $\mathrm{V}(\mathrm{V})$ complexes 15-17 [13].

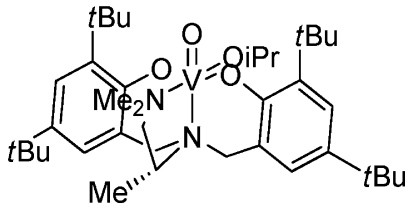

$(R)-17 \mathrm{~b}$

Table 3

Oxidation of thioanisole (11) by $\mathrm{H}_{2} \mathrm{O}_{2}$ with catalysts $\mathrm{VO}(\mathrm{acac})_{2} / \mathbf{1 4}, \mathbf{1 5}-\mathbf{1 7}^{\mathrm{a}}$ [13].

\begin{tabular}{|c|c|c|c|c|c|c|}
\hline Entry & Catalyst & Solvent & Temp. $\left({ }^{\circ} \mathrm{C}\right)$ & Time $(\mathrm{h})$ & Conv (\%) & Sulfone 13 (\%) \\
\hline 1 & $(R)-\mathbf{1 6 b}$ & DCE & 10 & 18 & 96 & 11 \\
\hline 2 & $(R)-\mathbf{1 6 b}$ & DCE & 0 & 24 & 27 & 1 \\
\hline 3 & $(R)-\mathbf{1 6 b}$ & DCE & 25 & 4 & 78 & 3 \\
\hline 4 & $(R)-\mathbf{1 6 b}$ & Acetone & 0 & 4 & $>99$ & 2 \\
\hline 5 & $(R)-\mathbf{1 7} \mathbf{b}$ & DCE & 10 & 20 & 93 & 5 \\
\hline 6 & $\mathrm{VO}(\mathrm{acac})_{2} / \mathbf{1 4 a}$ & DCE & 0 & 24 & 91 & 14 \\
\hline 7 & $\mathrm{VO}(\mathrm{acac})_{2} /(R)-\mathbf{1 4 b}$ & DCE & 0 & 24 & 91 & 6 \\
\hline
\end{tabular}

a Reactions carried out at $0-25^{\circ} \mathrm{C}$ with a $1: 1.2$ molar ratio of substrate/aq $\mathrm{H}_{2} \mathrm{O}_{2} ; 1 \%$ catalyst on 0.55 mmol scale.

Table 4

Oxidation of methyl $p$-tolyl sulfide 4 by CHP catalyzed by VO-POSS complex 18 (1\%) ${ }^{\text {a }}$ [14].

\begin{tabular}{llcc}
\hline Entry & Co-ligand & $t_{1 / 2} \mathrm{~S}$ (equiv. co ligand) & $\mathrm{SO}^{\mathrm{b}} \mathrm{SO}_{2}$ \\
\hline 1 & None & 6000 & $98: 2$ \\
2 & MeSOpTol & $5580(5)$ & $98: 2$ \\
4 & $\mathrm{HMPA}$ & $3042(5)$ & $93: 7$ \\
5 & $\mathrm{HMPA}$ & $456(150)$ & $68: 32$ \\
6 & $(\mathrm{nOct})_{3} \mathrm{PO}$ & $290(5)$ & $95: 5$ \\
7 & $\mathrm{HexMe}_{2} \mathrm{~N}^{+}-\mathrm{O}^{-}$ & $233(5)$ & $87: 13$ \\
\hline
\end{tabular}

a Reactions were carried out in $\mathrm{CHCl}_{3}$ at $28^{\circ} \mathrm{C}$ using $[\mathbf{4}]_{0}=[\mathrm{CHP}]_{0}=0.1 \mathrm{M}$ and $1 \mathrm{~mol} \%$ of $\mathbf{1 8}$.

b Time required for a $50 \%$ decrease of the initial concentration of 4 . 
<smiles>[R][Si]1(O)O[Si]([R])(O)O[Si]([R])(O)O[Si]2([R])O[Si]([R])(O[Si]([R])(O)O1)O2</smiles>

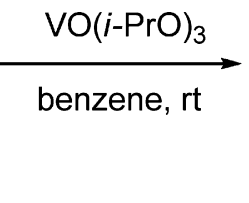

with two subsequent additions of oxidant at different temperatures (1.2 equiv. at $0{ }^{\circ} \mathrm{C}+0.3$ equiv. at $20^{\circ} \mathrm{C}$.) was set up. This new protocol allows the recovery of the $(R)$-sulfoxide with ees $=97 \%(44 \%)$. However, the best results were obtained working in chloroform, at $0{ }^{\circ} \mathrm{C}$ with only 1.2 equiv. of oxidant (catalyst:chiral ligand $=1 \%: 1.5 \%$ ): (R)-p-tolyl and 2-naphthyl methyl sulfoxides were obtained with ees $>99.5 \%$ in very good chemical yields (70 and $73 \%$ ). The method could be effectively used with a series of alkyl aryl sulfides with ees in the range of $87-99.5 \%$. The reactions could be carried out also on multigram scale.

Maguire and coworkers optimized the reaction protocol for the aryl benzyl sulfides [20]. Aryl benzyl sulfides can have a peculiar behavior in stereoselective sulfoxidation [21] and this depends on the occurrence of aromatic interactions between the substrates and the catalysts. Also in this case the diiodo Schiff base $19 \mathrm{c}\left(\mathrm{R}=\mathrm{R}^{\prime}=\mathrm{I}\right)$ affords the best stereoselectivities working in dichloromethane at room temperature (ees $>99 \%, 40-50 \%$ yield) with a series of aryl benzyl sulfides with selectivity factors up to 17.6. Interestingly also in this case higher selectivities were obtained at room temperature in dichloromethane $\left(S_{\mathrm{rt}}=4.6, S_{0}{ }^{\circ} \mathrm{C}=3.3\right)$ or at $0^{\circ} \mathrm{C}$ in chloroform $\left(S_{\mathrm{rt}}=5.8, S_{0}{ }^{\circ} \mathrm{C}=7.2\right)$.

More recently Li and coworkers took advantage of the combined stereoselective sulfoxidation/kinetic resolution for obtaining high ees in the oxidation of aryl alkyl sulfides [22]. They examined a series of different Schiff base ligands bearing two stereocenter at the $\beta$-amino alcohol arm. Among the ligands tested $23(1 \%)$ gave the best results (ees $\geq 99 \%$ ) with alkyl aryl sulfides in chloroform at $0{ }^{\circ} \mathrm{C}$ in the presence of 1.35 equiv. of $\mathrm{H}_{2} \mathrm{O}_{2}$. Also in this case the best stereoselectivities were obtained in chloroform at low temperature.

Gau and coworkers [23] determined the X-ray structures of

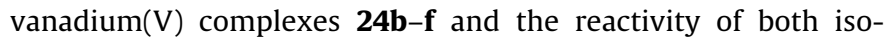
lated and in situ formed complexes reactivity in sulfoxidation was examined. The authors obtained comparable stereoselectivities and this is a strong indication that the active species are the same in both processes. All the isolated complexes have a squared pyramidal geometry. Complexes with $R^{3}=\mathrm{Bn}(\mathbf{2 4 c}, \mathbf{e}, \mathbf{f})$ adopt an endo-structure, in which the Bn substituent and the oxo group are on the same side of the pyramidal base, while 24d with $R^{3}=t$ $\mathrm{Bu}$ adopts an exo structure with the $t$-Bu trans to the oxo moiety (Fig. 7).

Pentadentate Schiff base $\mathbf{2 5}$ vanadium complexes have been synthesized and tested in sulfoxidation by Maeda (Fig. 8) [24]. The ligands are obtained from bis(aminoalkyl)amines salicyl aldehyde derivatives. The vanadium(IV) complexes displayed a distorted octahedral coordination in solid state, and they afforded lower rates of oxidation of the sulfide than the tetradentate salen ligands. The same group also reported on fourteen amino acids and amino acid ester Schiff base 26 (Fig. 8) and the corresponding V(V) complexes [25]. Peroxo complexes prepared from Schiff-base complexes of oxovanadium $(\mathrm{V})$ converted methyl phenyl sulfide in high yield but low ees (5-20\%). Other Schiff bases have been obtained using sugars $\mathbf{2 7}, \mathbf{2 8}[26,27]$. In the oxidation of thioanisole with hydrogen peroxide $\mathrm{V}(\mathrm{V}) / \mathbf{2 7}$ complexes afforded ees up to $60 \%$ [26] while $\mathrm{V}(\mathrm{V}) / \mathbf{2 8}$ ees up 26\% (Fig. 8) [27].

Interesting results have been obtained by Ahn and coworkers using Schiff bases of $\beta$-amino alcohols 29 and $\mathbf{3 0}$ [28]. The vanadium complexes obtained from these ligands are very effective in term of stereoselectivity of aryl benzyl sulfides (ees up to 96\%).

Zhu and coworkers reported high enantioselectivities in the asymmetric oxidation of sulfides using chiral vanadium complexes with salan ligands 31 in chloroform at $0^{\circ} \mathrm{C}$ [29]. The complex with 31a $\left(R=R^{\prime}=H\right)$ shows superior results in term of enantioselectivity than the corresponding salen analogue and provides the sulfoxides with opposite configuration. The presence of substituents in ortho-para positions of the aromatic ring, $\mathrm{N}$-methylation or the dichoromethane the kinetic resolution occurs only at at $0{ }^{\circ} \mathrm{C}$ the stereoselectivity of sulfide oxidation is higher. A protocol 
<smiles>[R]c1cc([R])c(O)c(/C=N/[C@@H]([R2])CO)c1</smiles>

19a $\mathrm{R}^{\prime \prime}=\mathrm{R}=\mathrm{R}^{\prime}=t-\mathrm{Bu}$

19b R"=R=t-Bu R'=NO

19c $\mathrm{R}^{\prime \prime}=t-\mathrm{Bu} ; \mathrm{R}=\mathrm{R}^{\prime}=\mathrm{I}$

19d R"=Bn; $R=R '=H$

19 e R"=i-Bu; $\mathrm{R}=\mathrm{R}^{\prime}=\mathrm{H}$<smiles>Oc1c(/C=N/[C@H]2c3ccccc3C[C@H]2O)cc2ccccc2c1-c1ccccc1</smiles><smiles>[R]c1cc(/C=N/[C@H](CO)C(C)(C)C)c(O)c(C(C)c2ccccc2)c1</smiles>

21<smiles>CC(C)(C)[C@H](CO)N=Cc1cc2ccccc2c(-c2cccc3ccccc23)c1O</smiles>

22<smiles>CC[C@H](O)[C@H](Cc1ccccc1)/N=C/c1cc(I)cc(I)c1O</smiles>

23

Fig. 5. Schiff base ligands 19-23 for V-catalyzed stereoselective sulfoxidation [16-23].

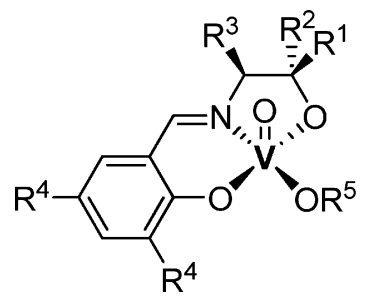

$$
\begin{aligned}
& \text { 24a } R^{1}=R^{2}=R^{4}=H, R^{3}=B n, R^{5}=H \\
& \text { 24b } R^{1}=R^{2}=R^{4}=H, R^{3}=i-B u, R^{5}=H \\
& \text { 24c } R^{1}=R^{2}=P h, R^{3}=B n, R^{4}=t-B u, R^{5}=E t \\
& \text { 24d } R^{1}=R^{2}=H, R^{3}=t-B u, R^{4}=H, R^{5}=E t \\
& \text { 24e } R^{1}=P h, R^{2}=H, R^{3}=B n, R^{4}=t-B u, R^{5}=E t \\
& \text { 24f } R^{1}=R^{2}=P h, R^{3}=B n, R^{4}=t-B u, R^{5}=i-P r
\end{aligned}
$$

Fig. 6. Isolated $V(V)$ catalysts $\mathbf{2 4 a}-\mathbf{f}[17]$.

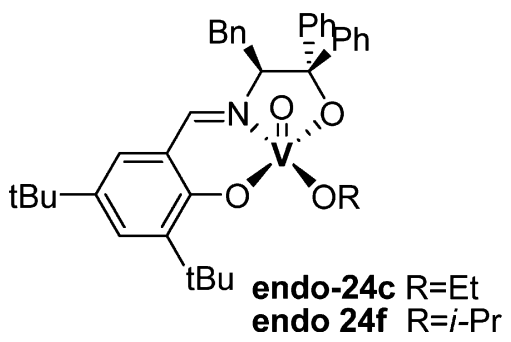<smiles>CCO[C@@]12OC[C@H](CC(C)(C)C)[N+]1=Cc1ccccc1O2</smiles>

exo-24d

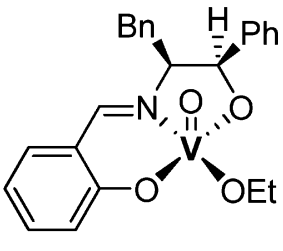

endo-24e

Fig. 7. Isolated complexes endo-24c, exo-24d, endo-24e and endo-24f [23].

use of different bis-amine backbones, solvents or higher reaction temperatures significantly decrease the selectivity of the system. More recently other research groups like Bryliakov and Talsi [30] or Correia and coworkers [31] explored the reactivity of analogous system finding much lower stereoselections. In particular Correia [31], working with isolated salan-complexes, reported opposite stereoselectivities with respect to the Zhu system.

Polymer bound vanadium complexes have been synthesized and used in sulfoxidation, in particular for the desulfurization of sulfur containing aromatic compounds like thiophene derivatives [32].

Schiff base ligands containing an histamine unit or 3formylsalicylic acid have been covalently bonded to chloromethylated polystyrene [32b] in some cases cross linked with divinylbenzene (5\%) [32a]. Treatment with $\mathrm{VO}(\mathrm{acac})_{2}$ eventually in the presence of oxygen gave the polymeric catalysts. The catalytic desulfurization has been carried out in apolar solvents at $60^{\circ} \mathrm{C}$ with $3-15 \%$ catalyst loading in the presence of three fold excess of hydrogen peroxide. Depending on the substrate, desulfurization of $70-99 \%$ was achieved in $2 \mathrm{~h}$. The systems were recycled up to three times without lost of activity.

\section{Epoxidations}

Chiral epoxides are key building blocks for the synthesis of natural products and biologically active compounds. Among the different methodologies available for their synthesis, the Ti(IV) catalyzed oxidation of allylic alcohols developed by Katsuki and Sharpless is, to date, the most efficient one [33]. On the other hand, this methodology presents some limitations, mainly the rather high catalysts loadings and anhydrous working conditions. Alternatively, vanadium catalyzed epoxidations have been explored. Vanadium is less moisture sensitive than titanium and permitted procedures with lower catalyst loading. After the pioneering work of Sharpless, who reported enantioselectivities up to $80 \%$ using a proline-based hydroxamic acid [34], another important achievement was reported by Yamamoto and coworkers in 2000 [35]. They designed a new chiral hydroxamic acid derived from tert-leucine 
<smiles>[R]c1cc([R])c(O)c(/C=N\N(C)NCCNC=NCc2cc([R])cc([R])c2O)c1</smiles>

25

$\mathrm{n}=2,3 ; \mathrm{R}^{1}=\mathrm{H}, \mathrm{MeO}, \mathrm{Cl}, t-\mathrm{Bu}, \mathrm{R}^{2}=\mathrm{H}, \mathrm{MeO}, \mathrm{NO}_{2}, \mathrm{Cl}, t-\mathrm{Bu}$<smiles>[R]OC(=O)C([R])/N=C/c1cc([R])cc([R])c1O</smiles>

$\mathrm{R}^{1}=\mathrm{H}, \mathrm{Cl}, \mathrm{NO}_{2}, \mathrm{R}^{2}=\mathrm{H}, \mathrm{Me}$ $\mathrm{R}^{3}=\mathrm{H}, \mathrm{CH}_{3}, \mathrm{Bn}, i-\mathrm{Pr}, \mathrm{CH}_{2} i-\mathrm{Pr}, n-\mathrm{Bu},\left(\mathrm{CH}_{2}\right)_{2} \mathrm{SCH}_{3}$ $\mathrm{CH}_{2}-4-\mathrm{Im},\left(\mathrm{CH}_{2}\right)_{4} \mathrm{NH}_{2}, \mathrm{CH}_{2} \mathrm{SH}$,

26<smiles>[R]c1ccc([R])c(/C=N/C[C@@H]2O[C@H](OC)[C@H](OC)[C@H](OC)[C@H]2O)c1O</smiles><smiles>[R]C(CO)N=Cc1cc2ccccc2c(-c2c(OC(=O)OC)ccc3ccccc23)c1O</smiles>

$\mathrm{R}=t-\mathrm{Bu}, \mathrm{C}(\mathrm{Et})_{2} \mathrm{OMe}$
27<smiles>[R]c1cc([R])c(O)c(/C=N\C)c1</smiles><smiles>CCCCOc1ccc2ccccc2c1-c1c(O)c(C=N[C@@H]2c3ccccc3C[C@H]2O)cc2ccccc12</smiles>

30<smiles>[R]c1cc([R])c(O)c(CN=[R]C2CCCCC2N([R])Cc2cc([R])cc([R])c2O)c1</smiles>

31a $R=R^{\prime}=H$

$31 \mathrm{~b} \mathrm{R}=t-\mathrm{Bu}, \mathrm{R}^{\prime}=\mathrm{H}$

31c $\mathrm{R}=\mathrm{H}, \mathrm{R}^{\prime}=\mathrm{Me}$

Fig. 8. Schiff base and salan type chiral ligands 24-31 [24-30].

able to afford good enantioselectivities in the epoxidation of disubstituted allylic alcohols in reasonable reaction times with only $1 \%$ catalyst loading and TBHP as oxidant.

In more recent years, research has been mainly focused on the improvement of the stereoselectivity, reducing catalyst loadings and using mild reaction conditions maintaining reasonable reaction rates. Another important issue of vanadium catalyzed epoxidations that has been addressed is the ligand deceleration effect. In fact, in these reactions the coordination of the ligand reduces the activity of the catalyst so the reactivity of the system is usually lower than that of the vanadium precursors $\left(\mathrm{VO}(\mathrm{acac})_{2}\right.$ or $\left.\mathrm{VO}(\mathrm{O}-i-\mathrm{Pr})_{3}\right)$. A common strategy to solve this problem is to work with excess of ligand. However, the excess of ligand must be controlled in order to disfavor the formation of the complex $\mathrm{L}_{2} \mathrm{VO}$ (ligand/vanadium $=2: 1$ ) that is inactive as catalyst in the epoxidation.

In addition to allylic alcohol epoxidation, studies have been performed in order to extend the applicability of vanadium catalysts to the epoxidation of homoallylic alcohols and less reactive olefins.

\subsection{Epoxidation of allylic and homoallylic alcohols}

After the discovery of hydroxamic acids as effective ligands for allylic alcohol oxidation, Yamamoto developed amino acid based chiral hydroxamic acid vanadium complexes for the stereoselective epoxidation of homoallylic alcohols [36]. In these systems the nature of the amino acid residue has an important effect on enan-<smiles>CC(C)(C)[C@H](C(=O)N(O)C(c1ccccc1)c1ccccc1)N1C(=O)c2ccccc2C1=O</smiles>

Fig. 9. tert-Leucine based hydroxamic acid 32 developed by Yamamoto [36]

tioselectivity, whereas the imido and the hydroxylamine motifs have little or no influence. Hydroxamic acid 32 derived from tertleucine (Fig. 9) affords highly stereoselective epoxidation of various homoallylic alcohols using $6 \%$ of the ligand, $2 \%$ of $\mathrm{VO}(\mathrm{O}-i-\mathrm{Pr})_{3}$ and cumene hydroperoxide as oxidant (Fig. 10). The system is particularly effective in the case of 3-monosubstituted homoallylic alcohols and enantioselectivities up to $91 \%$ were obtained at $0{ }^{\circ} \mathrm{C}$ in reasonable reaction times $(10 \mathrm{~h})$. The authors successfully applied this protocol in the key epoxidation step of the synthesis of $(-)-\alpha$ and (-)-8-epi- $\alpha$-bisabolol.

The quest for new ligands able to lower catalysts loading, to work with aqueous oxidants and avoid ligand deceleration led to the synthesis of a series of new chiral bis-hydroxamic acids 34 and 35 [37-39] readily available from the enantiomerically pure diamine tartrate salt (Fig. 11).

Ligands 34a, 34b and 35a were initially tested in the epoxidation of allylic alcohols [37,39]. The bis-hydroxamic acid catalytic sys- 
<smiles>CCC1OC1CCO</smiles>

$25 \%$ yield, $40 \%$ ee

33a<smiles>OCCC1OC1c1ccccc1</smiles>

$24 \%$ yield, $46 \%$ ee

33d<smiles>CC1(C)OC1CCO</smiles>

$67 \%$ yield, $36 \%$ ee<smiles>OCCC12CCCCC1O2</smiles>

$61 \%$ yield, $74 \%$ ee 33b<smiles>CC1(CCO)CO1</smiles>

$58 \%$ yield, $84 \%$ ee

$33 e$<smiles>OCCC1([Te])CO1</smiles>

$77 \%$ yield, $90 \%$ ee

$33 \mathrm{~h}$<smiles>OCCC1([18S])CO1</smiles>

$89 \%$ yield, $90 \%$ ee 33c<smiles>OCCC1(c2ccccc2)CO1</smiles>

$70 \%$ yield, $89 \%$ ee

$33 f$

Fig. 10. Homoallylic epoxides 33a-i by oxidation with VO/hydroxamic acid 32 catalyst. Conditions: 32 (6\%), $\operatorname{VO}(0-i$ - $P r)$ ( $2 \%)$, cumene hydroperoxide ( 1 equiv.) in toluene at $0{ }^{\circ} \mathrm{C}[36]$.<smiles>[R]C([R])C(=O)N(O)[C@H]1CCCC[C@H]1N(O)C(=O)C([R])[R]</smiles>

34a $\mathrm{R}=\mathrm{Ph}$

34b $R=3,5$-dimethylphenyl<smiles>[R3]CC(=O)N(O)[C@H]1CCCC[C@H]1N(O)C(=O)C[R3]</smiles>

35a $\mathrm{R}=\mathrm{Ph}$

35b R $=4$-tert-butylphenyl

35c $R=4-(2,4,6$-triethylphenyl)phenyl

35d R = 4-(2,4,6-trimethylphenyl)phenyl

Fig. 11. Yamamoto's bis-hydroxamic acids 34 and 35 [37-39].

tems were superior to the ones based on monohydroxamic acids. In fact (1) higher enantioselectivities than Ti(IV)-based systems were obtained, (2) aqueous TBHP could be used as oxidant, (3) the reactions could be run with as little as $0.2 \%$ of catalyst without decrease in enantioselectivity or reactivity, and (4) no ligand deceleration effect was observed when a ligand/vanadium ratio 3:1 was used. Under the optimized conditions (2\% ligand, $1 \%$ vanadium, DCM, $-20^{\circ} \mathrm{C}$ ), trans-monosubstituted and disubstituted allylic alcohols a)<smiles>OCC1(c2ccccc2)OC1[Pb]</smiles>

$91 \%$ yield, $97 \%$ ee

$36 \mathbf{a}$

b)<smiles>CC(C)=CCCC1(C)OC1CO</smiles>

$68 \%$ yield, $95 \%$ ee<smiles>CC1(CO)OC1c1ccccc1</smiles>

$84 \%$ yield, $97 \%$ ee $36 \mathrm{~b}$<smiles>CC(C)=CCCC1(C)OC1CO</smiles>

$62 \%$ yield, $95 \%$ ee<smiles>OCC1OC1c1ccccc1</smiles>

$53 \%$ yield, $97 \%$ ee

$36 c$

36d<smiles>CC1(c2ccccc2)OC1CO</smiles>

$64 \%$ yield, $96 \%$ ee

Fig. 12. Epoxidation of allylic alcohols using VO/bis-hydroxamic acid $\mathbf{3 4 a}$ (a) and $\mathbf{3 5 a}$ (b). Reaction conditions: 1 mol\% catalyst, $\mathrm{TBHP}$ (70\% aq), $\mathrm{CH} \mathrm{H}_{2} \mathrm{Cl} \mathrm{L}_{2}$ [37,39]. 


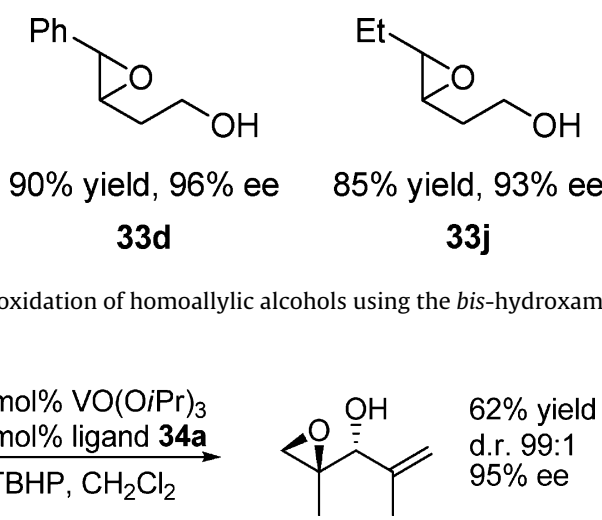

Scheme 4. Desymmetrization of allylic alcohols with ligand 34a [40].<smiles>O=C([C@@H](N[S-])c1ccccc1)N(O)C(c1ccccc1)c1ccccc1</smiles>

37

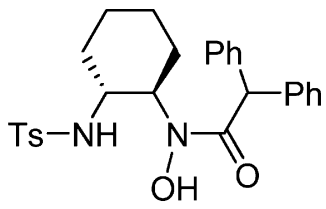

38
Fig. 14. Sulfonamide-based hydroxamic acid ligands $\mathbf{3 7}$ and $\mathbf{3 8}$ developed by Malkov [41-43].

were epoxidized with excellent enantioselectivities using ligand 34a, whereas ligand 35a was used for the enantioselective epoxidation of cis-substituted allylic alcohols [37] (Fig. 12). Low molecular weight allylic alcohols were also epoxidized with high enantioselectivities using the catalysts derived from $\mathbf{3 4 a}$, 34b or $\mathbf{3 5 a}[37,39]$ and the products could be obtained after extraction from the aqueous phase.

In the case of homoallylic alcohols ligand $\mathbf{3 5 c}$ was the most effective in terms of yields and enantioselectivities in the oxidation of substrates with highly hindered phenyl groups [38,39]. Excellent stereoselectivities were systematically obtained in the epoxidation of both cis- and trans-substituted homoallylic alcohols with CHP; for example in the synthesis of epoxide 33d the use of ligand 35c increases the ees from $46 \%$ (obtained with ligand 32, see Fig. 9 [36]) to $96 \%$ (Fig. 13). In addition, the system works at room temperature and allows the use of lower catalyst loading ( $2 \mathrm{~mol} \%$ ligand, ligand/metal ratio $2: 1$ ).

bis-Hydroxamic acid ligands were then used for the kinetic resolution of racemic allylic and homoallylic alcohols [37,38]. Working under the conditions optimized for the stereoselective epoxidation of achiral substrates it was possible to obtain both the starting alcohol and the epoxide with good stereoselectivities. The desymmetrization of meso secondary allylic alcohols and homoallylic alcohols was also successfully achieved [40]. Using $1 \%$ catalyst, the oxidizing system $\mathrm{VO}(\mathrm{O}-i-\mathrm{Pr})_{3} / \mathbf{3 4 a} / \mathrm{CHP}$ transformed trans-substituted and 1,1-disubstituted allylic alcohols with high yields and enantioselectivities (Scheme 4), while 35a was more efficient for cis-substituted substrates. In the case of meso homoallylic secondary alcohols it was observed that the system derived from ligand 35c ( $1 \mathrm{~mol} \% \mathrm{VO}(\mathrm{O}-i-\mathrm{Pr})_{3}, 2 \mathrm{~mol} \%$ ligand) was effective for cis alkenes but not for the trans ones.

Contemporarily to the development of bis-hydroxamic acidbased ligands, Malkov described a new series of sulfonamide-based hydroxamic acids (Fig. 14) [41].

Reactions carried out in the presence of ligand $\mathbf{3 7}$ afforded from moderate to good enantioselectivities in the epoxidation of trans monosubstituted allylic alcohols in toluene at $-20^{\circ} \mathrm{C}$ using TBHP as oxidant, but much lower reactivity and enantioselectiv-

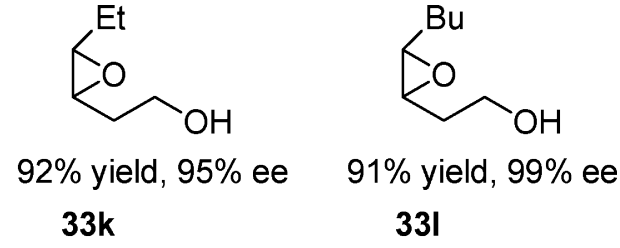

331 


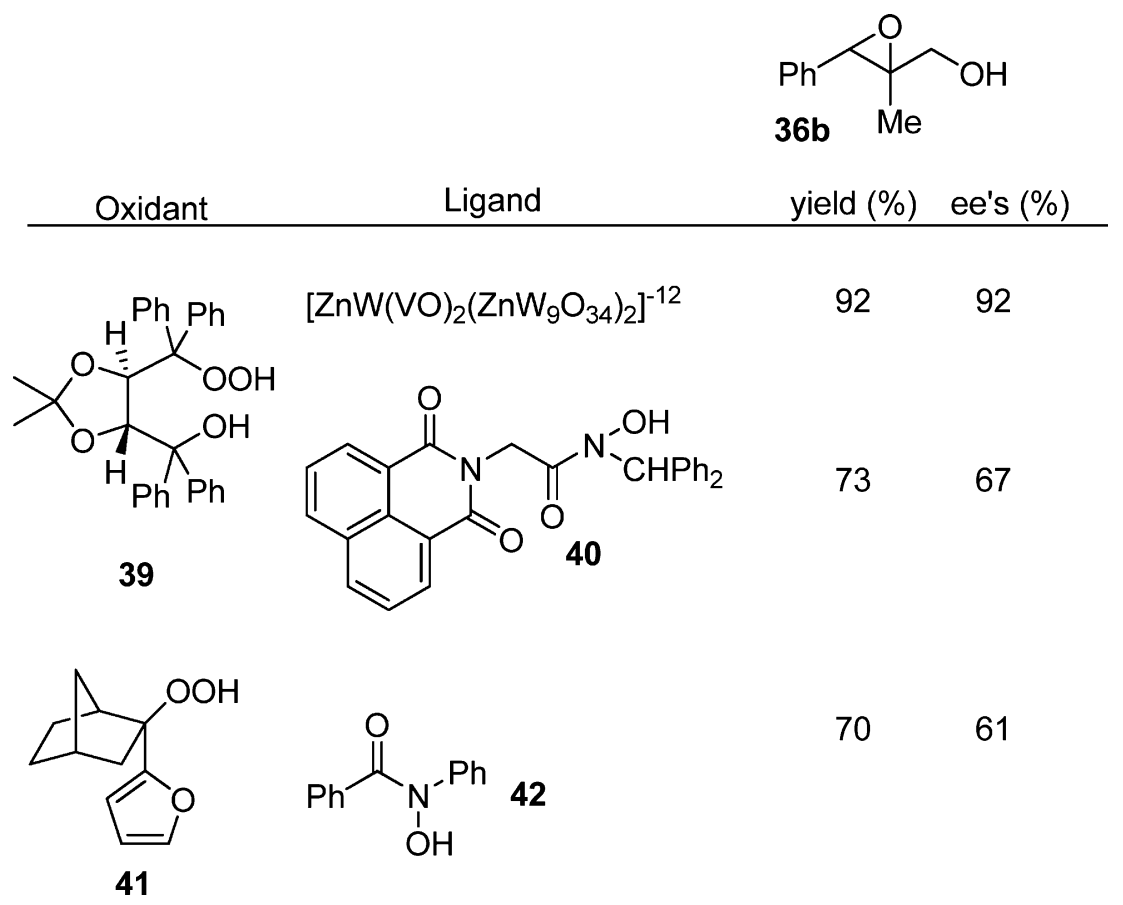

Scheme 6. Vanadium catalyzed epoxidation of allylic alcohols using chiral hydroperoxides 39 and $\mathbf{4 1}[45,47,48]$.

phenylbenzamide $\mathbf{4 2}$ as ligand [48]. Stereoselectivities up to $61 \%$ were achieved with epoxide $\mathbf{3 6 b}$ using $10 \%$ of catalyst and $15 \%$ of ligand (Scheme 6). Good stereoselectivities were obtained in for some selected substrates, however both systems are less active and stereoselective than the POM system described by Zhang.

Stereoselective vanadium catalyzed epoxidation of enantiopure allylic alcohols bearing an $\alpha$ sulfinyl moiety (VO(acac) $\left.)_{2} / \mathrm{TBHP}\right)$ has been reported by Fernández de la Pradilla and coworkers [49].

\subsection{Epoxidation of simple olefins}

Polyoxometalates (POMs) have been extensively studied as oxidation catalyst due to their robustness, ease of preparation and compatibility with different oxygen sources. Mizuno and coworkers reported that vanadium-based $\gamma$-Keggin type polyoxometalate $\left[\gamma-1,2-\mathrm{H}_{2} \mathrm{SiV}_{2} \mathrm{~W}_{10} \mathrm{O}_{40}\right]^{4-}$ which has a $\left\{\mathrm{VO}-(\mu-\mathrm{OH})_{2}-\mathrm{VO}\right\}$ core is an effective catalyst for the epoxidation of alkenes [50]. A series of linear and cyclic alkenes were efficiently oxidized using the tetrabutyl ammonium POM salt as catalyst (5\%) and $\mathrm{H}_{2} \mathrm{O}_{2}$ as oxidant (1 equiv.) (Fig. 15). Various non conjugated dienes were also oxidized with high regioselectivity for the less substituted double bond.

The epoxidation of cyclohexene with sandwich type polyoxometalates using chiral TADOOH as oxidant was reported by Zhang [45b]. Much lower reactivities and basically no stereoselectivities compared with the allylic alcohols were obtained (27\% yield with cyclohexene).

The oxidation of alkenes with oxygen using vanadium/Schiff base type ligands gave reasonable results only in the case of cyclooctene, while for other olefins very low conversions and selectivities were observed [51]. The catalytic activity of 4-acyl-5pyrazolone ligands in the oxidation of styrene, $\alpha$-methylstyrene and cis- $\beta$-methylstyrene with TBHP was also investigated [52], but as in the case of Schiff base ligands, very poor conversion and selectivity were obtained. Vanadium complexes derived from 2-(2-butoxyethoxy)ethanolate epoxidize cyclooctene with $68 \%$ conversions [53]. Amine triphenolate vanadium complexes have a scarce catalytic activity in styrene and trans-stilbene epoxidation [54].

\section{Haloperoxidations}

Selective bromination of organic compounds is a very important tool in organic synthesis. Organic bromo-derivatives are important precursors for various selective and efficient transformations in organic synthesis, as industrial intermediates and pharmaceuticals. Hazards and environmental problems correlated with classical bromination methods have encouraged the attention towards the development of safer and environmentally friendlier methods [55]. In this contest vanadium haloperoxidases (VHPOs), which have been isolated mainly from marine algae and fungi, have received much attention because they are able to catalyze the oxidation of halides to the corresponding hypohalous acid using hydrogen peroxide as primary oxidant [56]. Studies for determining the structure and activity of active sites in VHPOs and the synthesis of structural VHPOs models have stimulated the research on biomimetic vanadium systems as catalysts for haloperoxidation. Attention has been mainly focused on complexes which mimic the active sites of the enzyme [57,58] and, more recently, interest has moved towards the use of non conventional solvents, new oxidants or the heterogenization of the catalytic systems. This part of the review is dedicated to the recent advancements in this field.

Plass [59] reported that a $N$-salicylidene alkoxo vanadium(V) oxoperoxo complex which has, in the solid state, a pentagonalbipyramidal coordination geometry, with a side-on bonded peroxo ligand in the equatorial plane, is able to brominate, under stoichiometric conditions, 1,3,5-trimethoxybenzene (TMB) in the presence of tetrabutylammonium bromide ( $90 \%$ yield). More recently Xing et al. reported that oxovanadium(IV)-carboxylate complexes are effective systems in the bromination reaction of phenol red to bromophenol blue in phosphate buffer [60].

Licini and coworkers reported the $C_{3}$ vanadium $(\mathrm{V})$ amino triphenolate complexes 10a-c as structural and functional model of vanadium haloperoxidases [10]. These complex oxidize bromide and chloride ions by hydrogen peroxide, leading to the corresponding mono-halogen TMB. The catalyst loading has been lowered to $0.05 \%$ with respect to the limitation agent leading to the recovery of the BrTMB product in $63 \%$ yield with TONs up to 1260 . Reac- 
<smiles>C1CCC2OC2C1</smiles>

$90 \%$ yield

$43 a$

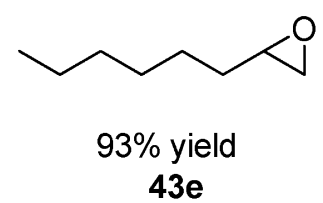<smiles>CC=CCC1(C)CO1</smiles>

$91 \%$ yield

43h

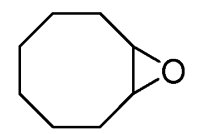

$93 \%$ yield

43b<smiles>CCCCCC1OC1C</smiles><smiles>[13CH3][13CH3]</smiles>

$43 f$<smiles>CC1=CC[C@H](C2(C)CO2)CC1</smiles>

$89 \%$ yield

$43 i$<smiles>CCC1CO1</smiles>

$91 \%$ yield

$43 c$<smiles>CC1CCCC2OC12</smiles>

$93 \%$ yield

syn/anti 5:95

$43 d$

Fig. 15. Epoxidation of alkenes using $\gamma$-Keggin type vanadium polyoxometalates [50].
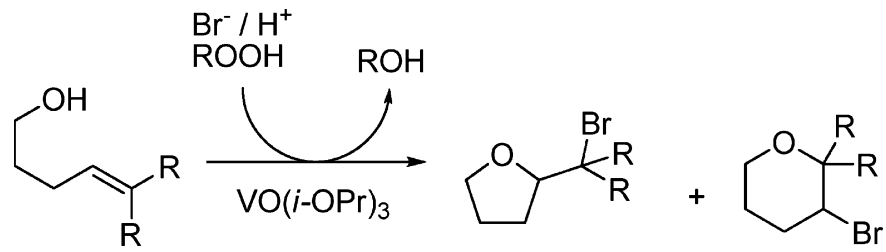

Scheme 7. Halocyclization of bis-homoallylic alcohols in the presence of bromide, $\mathrm{ROOH}$, and vanadium catalysts [63].

tions were also carried out in the presence of chloride ions. Slow chlorination of TMB could be achieved obtaining the corresponding chlorinated product in $40 \%$ yields after 2 days.

Conte et al. explored the possibility to perform haloperoxidation of styrene in ionic liquids using $\mathrm{NH}_{4} \mathrm{VO}_{3}$ as metal source, and hydrogen peroxide as oxidant [61]. Good to excellent yields of brominated products were obtained with styrene using imidazolium salts as solvent, much higher than in the corresponding two-phase $\mathrm{H}_{2} \mathrm{O} / \mathrm{CHCl}_{3}$ system [5]. Ionic liquids have also been successfully used in the oxidation of sulfides with the same systems [62].

The possibility to oxidize bromide ion has been used not only for bromoperoxidations but also for the combined halocyclization [63].

Hartung used (Schiff-base)vanadium(V) complexes to catalyze the oxidation of bromide for the stereoselective synthesis of functionalized cyclic ethers (Scheme 7). This methodology was effective for the synthesis of the 2,2,3,5,6,6-substituted tetrahydropyran nucleus of the marine natural product aplysiapyranoid $A$ 46 (Scheme 8). bis-Homoallylic alcohol 44 was treated with TBHP, pyridinium hydrobromide and $5 \mathrm{~mol} \%$ of $\operatorname{VOL}(\mathrm{OEt})(\mathrm{EtOH})[\mathrm{L}=\mathrm{N}-$ (2-hydroxyphenyl)salicylidene imine dianion] to furnish $43 \%$ of 6-endo-bromocyclized product 45 [63].

The mechanism of this bromination reaction consists of TBHP activation by mean of the vanadium complex, via in situ formation of the corresponding tert-butylperoxo complex. The metalloperoxo complex oxidizes bromide to $\mathrm{Br}_{2}$ as the active brominating reagent, which is released into the solution and serves as reagent for the halocyclization.

Heterogenization of vanadium complexes has been object of studies as well. New peroxovanadate complexes anchored to soluble polymers of the type, $\mathrm{Na}_{3}\left[\mathrm{~V}_{2} \mathrm{O}_{2}\left(\mathrm{O}_{2}\right)_{4}\right.$ (carboxylate)]-Pol $[\mathrm{Pol}=\operatorname{poly}($ acrylate $)$ or poly(methacrylate) $]$ have been synthesized from the reaction of $\mathrm{V}_{2} \mathrm{O}_{5}$ with $\mathrm{H}_{2} \mathrm{O}_{2}$ and the sodium salts of the respective macromolecular ligands [64]. Carboxylate groups of polymer chains are able to coordinate to $\mathrm{V}(\mathrm{V})$ centers. These supported peroxo species have been tested in bromination of aromatics compounds in acetonitrile-water media using tetraethyl ammonium bromide as bromide source. Activated aromatics, such as aniline, were brominated to produce predominantly $p$-bromo products (yields $75-95 \%$ ).

Heterogenization of vanadium complexes has been also reported by the group of Maurya and coworkers. In particular vanadium salts have been incorporated in polymeric Schiff bases [65], inserted in Na-Y zeolites [66], anchored to polystyrene resins [67] and reacted with polymer bound imidazole [68]. The latter system furnished the best results in term of product yield and capability to be recycled in the haloperoxidation of salicylic aldehyde. Under the optimized conditions, using aqueous $30 \% \mathrm{H}_{2} \mathrm{O}_{2}$, the supported catalyst, $\mathrm{KBr}$ and perchloric acid, $81.4 \%$ conversion of salicyl aldehyde was achieved. The supported catalyst can be reused without lost of activity (77.1\% of conversion after four cycles).

Vanadium complexes bearing organic ligands are not the only catalysts for haloperoxidation. Vanadium pentoxide $\left(\mathrm{V}_{2} \mathrm{O}_{5}\right)$ also very efficiently promotes the bromination of organic substrates in the presence of hydrogen peroxide [69]. However the method developed by Khan requires high catalyst loadings and a large excess of oxidant: typical conditions require $50 \%$ of $\mathrm{V}_{2} \mathrm{O}_{5}$ and 16 equiv. of $\mathrm{H}_{2} \mathrm{O}_{2}$. This methodology is useful for a wide range of substrates such as aromatic rings, olefins, chalcones, $\beta$-keto esters and 1,3-diketones Interestingly, the vanadium content can be reduced if a mineral acid, such as sulfuric acid, is used [70].

While all of the systems described use of peroxides as oxidation source, more recent catalytic systems capable of using oxygen as oxidant have been reported. Hirao and coworkers developed a catalytic system which performs oxidative bromination of arenes using ammonium metavanadate $\left(\mathrm{NH}_{4} \mathrm{VO}_{3}\right)$ in the presence of a bromide salt $\left(\mathrm{Bu}_{4} \mathrm{NBr}\right)$ and a Brønsted or Lewis acid in the presence of molecular oxygen [71]. This catalytic system has been applied to the bromination of alkenes and alkynes to give the corresponding vic-bromides, and to ketones to give $\alpha$-bromination. All these reactions furnish the products with excellent yields. 


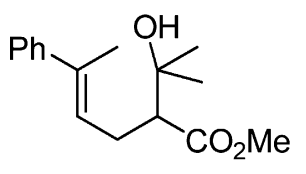

44
TBHP

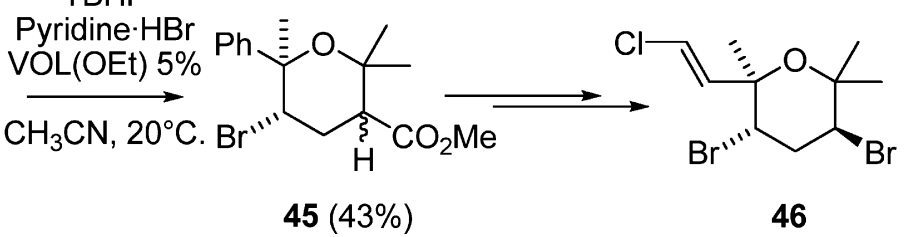

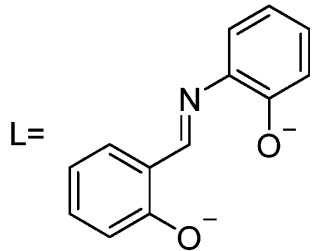

Scheme 8. Vanadium(V)-catalyzed oxidation of bromide in the 6-endo-selective bromocyclization of styrene-derived alcohol for the synthesis of aplysiapyranoid A 46 [63]

\section{Conclusions}

In this contribution we have shown that, in the last decade, important results have been obtained in oxygen transfer reactions catalyzed by vanadium complexes. In the field of stereoselective oxidation of sulfides, and epoxidation of allylic and homoallylic alcohols important results have been achieved. Even though it is still not possible always to use hydrogen peroxide in aqueous homogenous conditions, phase transfer systems or alkylperoxides have been used successfully in terms of yield and stereoselectivity. The capability of POM vanadium complexes to transfer oxygen to unfunctionalized olefins has been a major achievement. Haloperoxidations have seen also an increasing interest in the scientific community. Important results have been achieved in the bromination of organic substrates and in the field of halocyclization.

Important challenges remain. For example, the development of a vanadium catalyst able to transfer oxygen stereoselectively to unfunctionalized olefins or simple sulfides like dialkyl sulfides, and the development of catalyst able to work efficiently in the haloperoxidations. For the existing catalytic systems, the possibility to immobilize the catalyst in solid supports or to work in unconventional solvents in order to provide a "greener" process remains an important challenge.

\section{References}

[1] (a) G. Strukul (Ed.), Catalytic Oxidations with Hydrogen Peroxide as Oxidant Kluwer Academic Publishers, Dordrecht, 1992;

(b) W. Adam (Ed.), Peroxide Chemistry. Mechanistic and Preparative Aspects of Oxygen Transfer, Wiley-VCH Verlag GmbH, Weinheim, 2000;

(c) V. Conte, O. Bortolini, in: Z. Rappoport (Ed.), The Chemistry of Peroxides Transition Metal Peroxides Synthesis and Role in Oxidation Reactions, Wiley Interscience, 2006

[2] (a) M. Bonchio, G. Licini, F. Di Furia, S. Mantovani, G. Modena, W.A. Nugent, J. Org. Chem. 64 (1999) 1326;

(b) G. Licini, M. Bonchio, G. Modena, W.A. Nugent, Pure Appl. Chem. 71 (1999) 463.

[3] (a) C. Zonta, E. Cazzola, M. Mba, G. Licini, Adv. Synth. Catal. 350 (2008) 2503; (b) M. Forcato, M. Mba, W.A. Nugent, G. Licini, Eur. J. Org. Chem. (2010) 740; (c) M. Mba, L.J. Prins, C. Zonta, M. Cametti, A. Valkonen, K. Rissanen, G. Licini, Dalton Trans. 39 (2010) 7384;

(d) G. Santoni, M. Mba, M. Bonchio, W.A. Nugent, C. Zonta, G. Licini, Chem. Eur. J. $16(2010) 645$.

[4] F. Romano, A. Linden, M. Mba, C. Zonta, G. Licini, Adv. Synth. Catal. 352 (2010) 2937.

[5] (a) V. Conte, B. Floris, Inorg. Chim. Acta 363 (2010) 1935;

(b) V. Conte, B. Floris, Dalton Trans. 40 (2011) 1419.

[6] (a) H. Vilter, Phytochemistry 23 (1984) 1387;

(b) M.A. Andersson, A. Willetts, S.G. Allenmark, J. Org. Chem. (1997) 8455; (c) A.G.J. Ligtenbarg, R. Hage, B.L. Feringa, Coord. Chem. Rev. 237 (2003) 98.

[7] (a) C. Bolm, Coord. Chem. Rev. 237 (2003) 245;

(b) E. Wojaczyska, J. Wojaczyski, Chem. Rev. 110 (2010) 4303.

[8] (a) G. Santoni, G. Licini, D. Rehder, Chem. Eur. J. 9 (2003) 4700;

(b) C. Wikete, W. Pingsong, G. Zampella, L. De Gioia, G. Licini, D. Rehder, Inorg. Chem. 46 (2007) 196;

(c) W. Pingsong, C. Çelik, G. Santoni, J. Dallery, D. Rehder, Eur. J. Inorg. Chem. (2008) 5203.

[9] A. Martinez, J.-P. Dutasta, J. Catal. 267 (2009) 188.

[10] M. Mba, M. Pontini, S. Lovat, C. Zonta, G. Bernardinelli, E.P. Kündig, G. Licini, Inorg. Chem. 47 (2008) 8616.

[11] L.J. Prins, M. Mba, A. Kolarović, G. Licini, Tetrahedron Lett. 47 (2006) 2735.

[12] S. Barroso, P. Adão, MadeiraF P., M.T. Duarte, J. Costa Pessoa, A.M. Martins, Inorg. Chem. 49 (2010) 7452.

[13] E.Y.Tshuva, M. Versano, I. Goldberg, M. Kol, H. Weitman, Z. Goldschimidt, Inorg Chem. Commun. 2 (1999) 371.
[14] S. Lovat, M. Mba, H.C.L. Abbenhuis, D. Vogt, C. Zonta, G. Licini, Inorg. Chem. 48 (2009) 4724.

[15] F. Carniato, E. Boccaleri, L. Marchese, A. Fina, D. Tabuani, G. Camino, Eur. J. Inorg. Chem. 4 (2007) 585.

[16] C. Bolm, F. Bienewald, Angew. Chem. Int. Ed. Engl. 34 (1995) 2640.

[17] Q. Zeng, H. Wang, T. Wang, Y. Cai, W. Weng, Y. Zhao, Adv. Synth. Catal. 347 (2005) 1933.

[18] (a) H.B. Kagan, J.C. Fiaud, in: E.L. Eliel, S.H. Wilen (Eds.), Topics in Stereochemistry, vol. 18, John Wiley \& Sons, 1988, p. 249;

(b) C.J. Sih, S.H. Wu, in: E.L. Eliel, S.H. Wilen (Eds.), Topics in Stereochemistry, vol. 18, John Wiley \& Sons, 1988, p. 63, vol. 19.

[19] (a) C. Drago, L. Caggiano, R.F.W. Jackson, Angew. Chem. Int. Ed. 44 (2005) 7221; (b) M. Hinch, O. Jacques, C. Drago, L. Caggiano, R.F.W. Jackson, C. Dexter, M.S. Anson, S.J.F. Macdonald, J. Mol. Chem. A: Chem. 251 (2006) 123.

[20] P. Kelly, S.E. Lawrence, A.R. Maguire, Eur. J. Org. Chem. (2006) 4500.

[21] (a) F. Di Furia, G. Licini, G. Modena, R. Motterle, W.A. Nugent, J. Org. Chem. 61 (1996) 5175;

(b) M.I. Donnoli, S. Superchi, C. Rosini, J. Org. Chem. 63 (1998) 9392;

(c) P. Axe, S.D. Bull, M.G. Davidson, M.D. Jones, D.E.J.E. Robinson, W.L. Mitchell, J.E. Warren, Dalton Trans. 46 (2009) 10169

[22] Y. Wu, J. Liu, X. Li, A.S.C. Chan, Eur. J. Org. Chem. (2009) 2607.

[23] S.-H. Hsieh, Y.-P. Kuo, H.-M. Gau, Dalton Trans. (2007) 97.

[24] R. Ando, S. Mori, M. Hayashi, T. Yagyu, M. Maeda, Inorg. Chim. Acta (2004) 1177.

[25] R. Ando, H. Inden, M. Sugino, H. Ono, D. Sakaeda, T. Yagyu, M. Maeda, Inorg. Chim. Acta (2004) 1337.

[26] M.E. Cucciolito, R. Del Litto, G. Roviello, F. Ruffo, J. Mol. Catal. A: Chem. 236 (2005) 176.

[27] I. Lippold, J. Becher, D. Klemm, W. Plass, J. Mol. Catal. A: Chem. 299 (2009) 12.

[28] (a) Y.-C. Jeong, S. Choi, Y.D. Huang, K.-H. Ahn, Tetrahedron Lett. 45 (2004) 9249 (b) Y.-C. Jeong, Y.D. Huang, S. Choi, K.-H. Ahn, Tetrahedron: Asymmetry 16 (2005) 3497.

[29] J. Sun, C. Zhu, Z. Dai, M. Yang, Y. Pan, H. Hu, J. Org. Chem. 69 (2004) 8500.

[30] K.P. Bryliakov, E.P. Talsi, Eur. J. Org. Chem. (2008) 3369.

[31] P. Adão, J. Costa Pessoa, R.T. Henriques, M.L. Kuznetsov, F. Avecilla, M.R. Maurya, U. Kumar, I. Correia, Inorg. Chem. 48 (2009) 3542

[32] (a) M.R. Maurya, A. Arya, A. Kumar, J. Costa Pessoa, Dalton Trans. (2009) 2185; (b) M.R. Maurya, A. Arya, A. Kumar, M.L. Kuznetsov, F. Avecilla, J. Costa Pessoa, Dalton Trans. 49 (2010) 6586.

[33] T. Katsuki, K.B. Sharpless, J. Am. Chem. Soc. 102 (1980) 5974.

[34] (a) R.C. Michaelson, R.E. Palermo, K.B. Sharpless, J. Am. Chem. Soc. 99 (1977) 1990 ;

(b) K.B. Sharpless, T.R. Verhoeven, Aldrichim. Acta 12 (1979) 63.

[35] Y. Hoshino, H. Yamamoto, J. Am. Chem. Soc. 122 (2000) 10452.

[36] N. Makita, Y. Hoshino, H. Yamamoto, Angew. Chem. Int. Ed. 42 (2003) 941.

[37] W. Zhang, A. Basak, Y. Kosugi, Y. Hoshino, H. Yamamoto, Angew. Chem. Int. Ed. 44 (2005) 4389.

[38] W. Zhang, H. Yamamoto, J. Am. Chem. Soc. 128 (2007) 286

[39] A.U. Barlan, W. Zhang, H. Yamamoto, Tetrahedron 63 (2007) 6075.

[40] Z. Li, W. Zhang, H. Yamamoto, Angew. Chem. Int. Ed. 47 (2008) 7520.

[41] A.V. Malkov, Z. Bourhani, P. Kočovský, Org. Biomol. Chem. 3 (2005) 3194.

[42] Z. Bourhani, A.V. Malkov, Chem. Commun. (2005) 4592.

[43] A.V. Malkov, L. Czemerys, D.A. Malyshev, J. Org. Chem. 74 (2009) 3350.

[44] K.P. Bryliakov, E.P. Talsi, S.N. Stas'ko, O.A. Kholdeeva, S.A. Popov, A.V. Tkachev, J. Mol. Catal. A: Chem. 194 (2003) 79.

[45] (a) W. Adam, P.L. Alster, R. Neumann, C.R. Saha-Möller, D. Seebach, R. Zhang, Org. Lett. 5 (2003) 725;

(b) W. Adam, P.L. Alster, R. Neumann, C.R. Saha-Möller, D. Seebach, A.K. Beck, R. Zhang, J. Org. Chem. 68 (2003) 8222.

[46] M. Aoki, D. Seebach, Helv. Chim. Acta 84 (2001) 187.

[47] W. Adam, A.K. Beck, A. Pichota, C.R. Saha-Möller, D. Seebach, N. Vogl, R. Zhang, Tetrahedron: Asymmetry 14 (2003) 1355.

[48] A. Lattanzi, S. Piccirillo, A. Scettri, Eur. J. Org. Chem. (2005) 1669.

[49] R. Fernández de la Pradilla, A. Castellanos, J. Fernández, M. Lorenzo, P. Manzano, P. Méndez, J. Priego, A. Viso, J. Org. Chem. 71 (2006) 1569.

[50] (a) Y. Nakagawa, K. Kamata, M. Kotami, K. Yamaguchi, N. Mizuno, Angew. Chem. Int. Ed. 44 (2005) 5136;

(b) N. Mizuno, Y. Nakagawa, K. Yamaguchi, J. Mol. Catal. A: Chem. 251 (2006) 286.

[51] (a) D.M. Boghaei, A. Bezaatpour, M. Behzad, J. Mol. Catal. A: Chem. 245 (2006) 12 ;

(b) S. Mohebbi, A.H. Sarvestani, Transit. Met. Chem. 31 (2006) 749;

(c) S. Rayati, N. Torabi, A. Ghaemi, S. Mohebbi, A. Wojtczak, A. Kozakiewicz, Inorg. Chim. Acta 361 (2008) 1239; 
(d) S. Rayati, M. Koliaei, F. Ashouri, S. Mohebbi, A. Wojtczak, A. Kozakiewicz, Appl. Catal. A: Gen. 346 (2008) 65;

(e) H.H. Monfared, R. Bikas, P. Mayer, Inorg. Chim. Acta 363 (2010) 2574

[52] F. Marchetti, C. Pettinari, C. Di Nicola, R. Pettinari, A. Crispini, M. Crucianelli, A. Di Giuseppe, Appl. Catal. A: Gen. 378 (2010) 211.

[53] E.C.E. Rosenthal, H. Cui, M. Hummert, Inorg. Chem. Commun. 11 (2008) 918.

[54] S. Groysman, I. Goldberg, Z. Goldschmidt, M. Kol, Inorg. Chem. 44 (2005) 5073.

[55] A. Podgoršek, M. Zupan, J. Iskra, Angew. Chem. Int. Ed. 48 (2009) 8424.

[56] (a) A. Butler, Coord. Chem. Rev. 187 (1999) 17;

(b) V.M. Dembitsky, Tetrahedron 59 (2003) 4701.

[57] (a) R. de La Rosa, M.J. Clague, A. Butler, J. Am. Chem. Soc. 114 (1992) 760; (b) M.J. Clague, N.L. Keder, A. Butler, Inorg. Chem. 32 (1993) 4754

[58] (a) D.C. Crans, J.J. Smee, E. Gaidamauskas, L.Q. Yang, Chem. Rev. 104 (2004) 849; (b) G.J. Colpas, B.J. Hamstra, J.W. Kampf, V.L. Pecoraro, J. Am. Chem. Soc. 118 (1996) 3469;

(c) A. Butler, M.J. Clague, G.E. Meister, Chem. Rev. 94 (1994) 625.

[59] S. Nica, A. Pohlmann, W. Plass, Eur. J. Inorg. Chem. (2005) 2032.

[60] (a) Z.-P. Li, Y.-H. Xing, Y.-Z. Cao, X.-Q. Zeng, M.-F. Ge, S.-Y. Niu, Polyhedron 28 (2009) 865;

(b) Z.-P. Li, Y.-H. Xing, C.-G. Wang, J. Li, Y.-Z. Cao, X.-Q. Zeng, M.-F. Ge, S.-Y. Niu, Z. Anorg. Allg. Chem. 63 (2009) 2601.

[61] V. Conte, B. Floris, P. Galloni, A. Silvagni, Pure Appl. Chem. 77 (2005) 1575.
[62] V. Conte, F. Fabbianesi, B. Floris, P. Galloni, D. Sordi, I.C.W.E. Arends, M. Bonchio, D. Rehder, D. Bogdal, Pure Appl. Chem. 81 (2009) 1265.

[63] (a) M. Greb, J. Hartung, F. Kőhler, K. Špehar, R. Kluge, R. Csuk, Eur. J. Org. Chem. (2004) 3799;

(b) J. Hartung, Pure Appl. Chem. 77 (2005) 1559.

[64] D. Kalita, S. Sarmah, S. Prasad Das, D. Baishya, A. Patowary, S. Baruah, N.S. Islam, React. Funct. Polym. (2008) 876.

[65] M.R. Maurya, A. Kumar, P. Manikandan, S. Chand, Appl. Catal. A: Gen. 277 (2004) 45.

[66] M.R. Maurya, H. Saklani, S. Agarwal, Catal. Commun. 5 (2000) 563

[67] (a) M.R. Maurya, S. Sikarwar, T. Joseph, P. Manikandan, S.B. Halligudi, React. Funct. Polym. 63 (2005) 71;

(b) M.R. Maurya, U. Kumar, P. Manikandan, Dalton Trans. (2006) 3561.

[68] M.R. Maurya, M. Kumar, A. Arya, Catal. Commun. 10 (2008) 187

[69] (a) U. Bora, G. Bose, M.K. Chaudhuri, S.S. Dhar, R. Gopinath, A.T. Khan, B.K. Patel, Org. Lett. 2 (2000) 247;

(b) A.T. Khan, P. Goswami, Tetrahedron Lett. 46 (2005) 4937;

(c) A.T. Khan, P. Goswami, L.H. Choudhury, Tetrahedron Lett. 47 (2006) 2751.

[70] G. Rothenberg, J.H. Clark, Org. Process Res. Dev. 4 (2000) 270.

[71] (a) K. Kikushoma, T. Moriuchi, T. Hirao, Asian J. Chem. 4 (2009) 1213;

(b) K. Kikushima, T. Moriuchi, T. Hirao, Tetrahedron Lett. 51 (2010) 340;

(c) K. Kikushima, T. Moriuchi, T. Hirao, Tetrahedron 66 (2010) 6906 